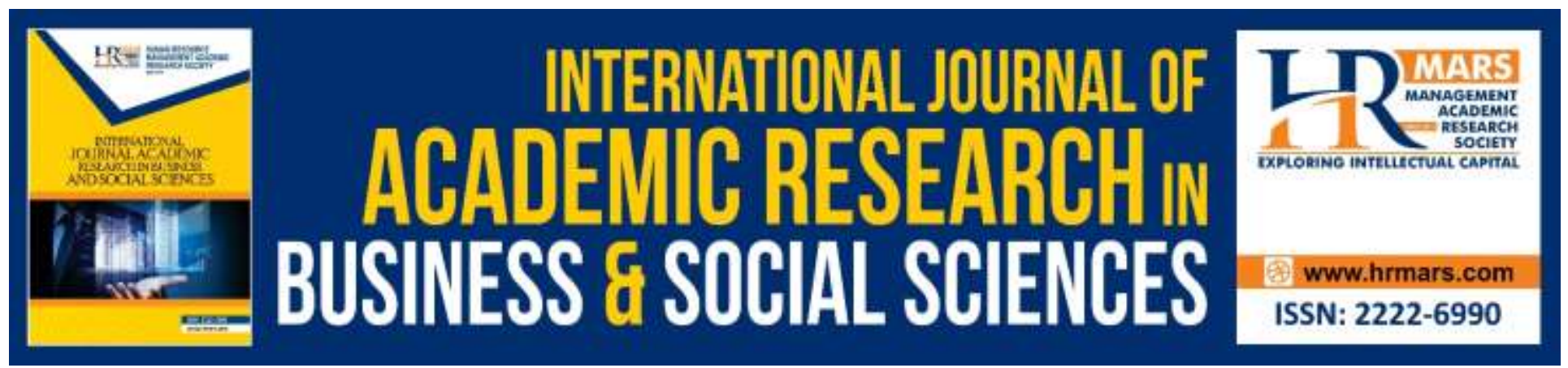

\title{
The Effect of Malaysian Teenagers Resources, Influence Strategies and Family Purchase Decision
}

\author{
Amily Fikry, Nabsiah Abdul Wahid, Mahmod Sabri Haron
}

To Link this Article: http://dx.doi.org/10.6007/IJARBSS/v10-i6/7331

DOI:10.6007/IJARBSS/v10-i6/7331

Received: 25 April 2020, Revised: 27 May 2020, Accepted: 06 June 2020

Published Online: 30 June 2020

In-Text Citation: (Fikry et al., 2020)

To Cite this Article: Fikry, A., Wahid, N. A., \& Haron, M. S. (2020). The Effect of Malaysian Teenagers Resources, Influence Strategies and Family Purchase Decision. International Journal of Academic Research in Business and Social Sciences, 10(6), 533-559.

Copyright: (C) 2020 The Author(s)

Published by Human Resource Management Academic Research Society (www.hrmars.com)

This article is published under the Creative Commons Attribution (CC BY 4.0) license. Anyone may reproduce, distribute, translate and create derivative works of this article (for both commercial and non-commercial purposes), subject to full attribution to the original publication and authors. The full terms of this license may be seen

at: http://creativecommons.org/licences/by/4.0/legalcode

Vol. 10, No. 6, 2020, Pg. 533 - 559

http://hrmars.com/index.php/pages/detail/IJARBSS

JOURNAL HOMEPAGE

Full Terms \& Conditions of access and use can be found at http://hrmars.com/index.php/pages/detail/publication-ethics 


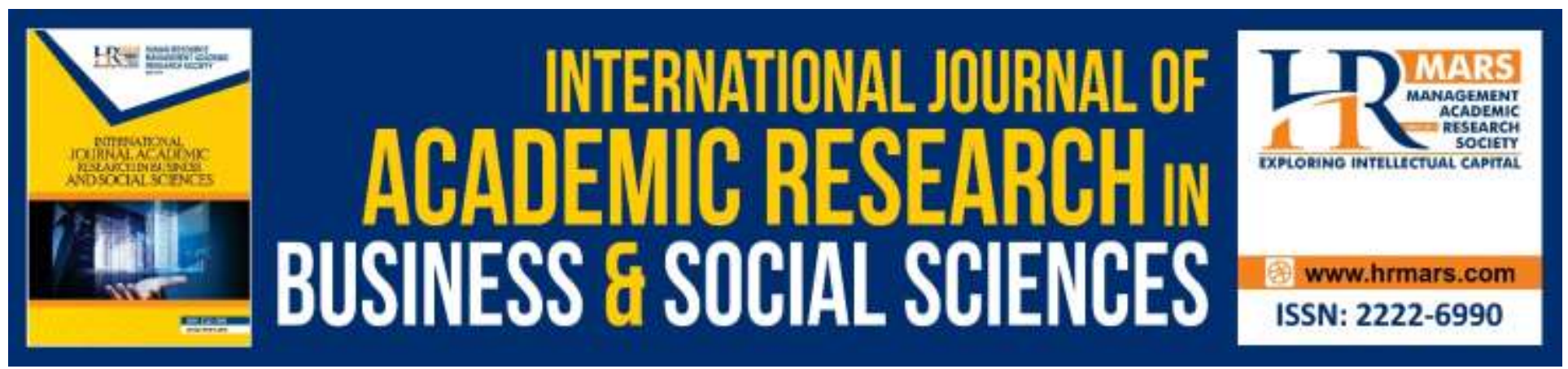

\title{
The Effect of Malaysian Teenagers Resources, Influence Strategies and Family Purchase Decision
}

\author{
Amily Fikry \\ Amily Fikry, Faculty of Business and Management, Universiti Teknologi MARA Campus Selangor, \\ 42300 Puncak Alam, Selangor, Malaysia.
}

Nabsiah Abdul Wahid

Graduate School of Business, Universiti Sains Malaysia, 11800 Pulau Pinang

Mahmod Sabri Haron

School of Management, Universiti Sains Malaysia, 11800 Pulau Pinang

Email: amily@uitm.edu.my, amilyfikryaziz@gmail.com

\begin{abstract}
Purpose: This research attempts to determine the effect of resources and influence strategies on the family purchase decision.
\end{abstract}

Design/methodology/approach: This research used a structured questionnaire to collect data on teenager's influence on family purchase decision. Factor analyses, reliability and multiple regression were used to analysed the data.

Findings: The findings show that teenagers use persuasion and bargaining strategies to influence their family purchase decision (to some extent).

Originality/value: The research of family purchase decision usually ignores the influence of children, such as teenagers. Most of the previous researchers tended to concentrate on decision-making made by husbands and wives and claimed it as a family decision making. This, however, may not hold since family also comprises of other members such as children. Thus, this paper attempts to focus on other family members i.e. teenagers influence in family purchase decision.

Keywords: Family Purchase Decision, Mobile Phone, Resources, Influence Strategies, Teenagers.

\section{Introduction}

Teenagers are categorized as 'hyper consumers' (Chaplin \& John, 2005) who are able to influence family purchase decision (Bansal, 2004; Dobrow, 2006; Spero \& Stone, 2004; Stone, Stanton, Kirkham, \& Pyne, 2001) for a specific category of products such as VCRs, autos, computers, stereos, vacation (Spiers, 2017; Vishwakarma \& Chatterjee, 2018) and sporting equipment (McLaughlin, 2000; Opara and Uboegbulam, 2016) due to trust and the busy lifestyle of their parents (Brazil, 1999). However, the level of the teen's influence on family purchase decision also differs across several elements, i.e. 
culture (Shoham \& Dalakas, 2003), ethnicity (Opara \& Uboegbulam, 2016), gender (Lee \& Collins, 2000), age group (Sharma \& Sonwaney, 2014) and country (Lee \& Marshall, 1998; Vishwakarma \& Chatterjee, 2018). Other than the elements as mentioned earlier, the level of the teen's influence towards family purchase decision also differs according to resources. Nevertheless, limited research has been done to examine the relationship between resources and family purchase decision. Only Abdul Rahman (2003), Beatty and Talpade (1994), Foxman, Tansuhaj and Ekstrom (1989a) and McNeal and Yeh (1997) focused on the study of resources. The extent of the relationship, if any, among resources (i.e. teenagers' resources), influence strategies and family purchase decision are still unclear.

Also, teenagers are said to be disloyal to particular brands (Cora, 2019; Duh \& lyiola, 2020; Taylor \& Cosenza, 2002) and adaptable to the latest technology (Bansal, 2004; Becker, 2005; Dobrow, 2006; Johnson, 2006; Kaur \& Medury, 2011; Stone et al., 2001; Wilska, 2003; Dikcius et.al; 2018). Considering their product skills and knowledge, there is no doubt that parents depend on their (teenagers) decisions to purchase products for the family. Parents feel that their older children have more experience and knowledge about products (Brazil, 1999; Kaur \& Medury, 2011; Mangleburg, 1990). Parents also perceive that their teenagers have higher consumer skills, are more rational, and could comprehend basic economic concepts (Brazil, 1999; Roedder, 1981) as compared to younger children who are below the teen's age group. Ward and Wackman (1972) found that children's influence attempt decreased with age, but parents' yielding to the child's request increased with age. This is due to the reason that mothers trust the judgments made by their children as their children get older (Ward, 1974).

\section{Research Objectives}

This study attempts to answer one broad objective, i.e. the influence of teenagers on a family purchase decision. In answering this broad objective, three specific objectives have been developed for this research. The objectives of this research are as follows:

1. To determine the significant relationship between the teenager's resource/s and family purchase decision.

2. To determine the significant relationship between the teenager's resource/s and influence strategies.

3. To determine the significant relationship between influence strategies and family purchase decision.

\section{Scope of The Study}

This study focuses on a group of teenagers in private academic secondary schools (at the ages of 13 to 17 years old) who use mobile phones worth RM 500 and above. This is because, based on the researcher's observation and personal interviews with the mobile phone sellers at the retail outlets, it was found that majority of these mobile phones comprised of features that were of interest to a majority of the teenagers (Bressler, 2006; Geser, 2004; Johnson, 2006; Lasica, 2007; May \& Hearn, 2005; Wilska, 2003; Würfel, 2007). The features of these mobile phones reflect the nature of the mobile phone (in the price range of RM 500 and above) as a shopping product. The classifications of the mobile phone as shopping products (Røpke, 2003) are characterized as having a less frequent purchase, high consumer involvement and complex decision-making. These are also related to the three conditions of complex decision-making. The three conditions for complex decision- making of 
a product are nature of the product itself (i.e. high priced complex products are associated with highperformance risks and one's ego), sufficient time for extensive information search and processing, and the availability of adequate information to evaluate alternative brands of the product (Assael, 1990, 1998).

Looking at the Malaysian scenario, it is noted that the mobile phone is seriously considered as a shopping product among Malaysian teenagers. The purchase of the mobile phone involves high consumer involvement and complex decision-making which also affects one's ego. Mobile phones are also associated with a high-priced complex product with high-performance risks due to its nature as a technological gadget with various functions and specifications. One may purchase the mobile phone with a high pixel camera (i.e. 2 megapixels to 5 megapixels), a high quality surrounded sound features of FM radio, Java games, MP 3 song player, internet speed (i.e. from GPRS to 3G), blue tooth, infrared, and a high memory storage (from memory card of 256 megabytes to 3 gigabytes). Due to that, sufficient time is needed for extensive search and processing of information on mobile phones. This is because the more functions and the higher the specifications of the mobile phones, the more complex and expensive the mobile phones will be. As a result, there is a need to obtain adequate information on the availability of alternative brands of mobile phones. As shopping products with high consumer involvement and complex decision- making, the decision to purchase mobile phones require teenagers to go through the decision process with their parents. As a result, the purchase of mobile phones for teenagers require the consent of their parents.

\section{Literature Review}

Teenager's resources and family purchase decision

Several works of literature have supported the association between resources and family purchase decision (Foxman, Tansuhaj \& Ekstrom, 1989a, 1989b). Children's resources were also found to have a significant positive relationship to family purchase decision for family vacation and self-use toy products (Flurry, 2007), and innovative products (Dikcius et.al, 2018). Zooming to the resource theory (Blood and Wolfe,1960), by treating knowledge as a resource, it is believed that those who are more knowledgeable will be in a better position to influence family purchase decision (Beatty \& Talpade, 1994). Teenagers are believed to possess more resources due to their accumulated knowledge, elevated status as perceived by parents (Dikcius et.al, 2018).

In their study, Beatty and Talpade found no relationship between the teen's perceived product knowledge and perceived relative influence on the family decision-making for durable products for the family. Partial support for the relationship between the teen's perceived knowledge and family purchase of durables for the teen's use. Wang et al. (2007) found a significant relationship among teenager's product knowledge, relative influence and the initiation stage of the family purchase decision. A significant relationship was also found between the teenager's importance and usage, relative influence and all stages of family purchase decision (initiation and final decision stage) (Wang et al., 2007). Contrarily, Lührmann, Serra-Garcia \& Winter (2012) revealed that teenagers have insufficient financial knowledge which may affect their product's purchase decision.

Also, it was found that the level of product importance to teens would increase the perceived relative influence for family decision making of durable products for the family (Beatty \& Talpade, 1994). Foxman, Tansuhaj and Ekstrom (1989a) revealed that the teen's importance of the products affected the teen's influence in family decision-making. The theoretical framework was developed, taking into 
INTERNATIONAL JOURNAL OF ACADEMIC RESEARCH IN BUSINESS AND SOCIAL SCIENCES Vol. 10, No. 6, June, 2020, E-ISSN: 2222-6990 @ 2020 HRMARS

consideration the gaps in the previous studies and the purpose of meeting the specific objectives of the present study (Figure 1). The following hypotheses have been formulated as well.

Figure 1: Theoretical Framework

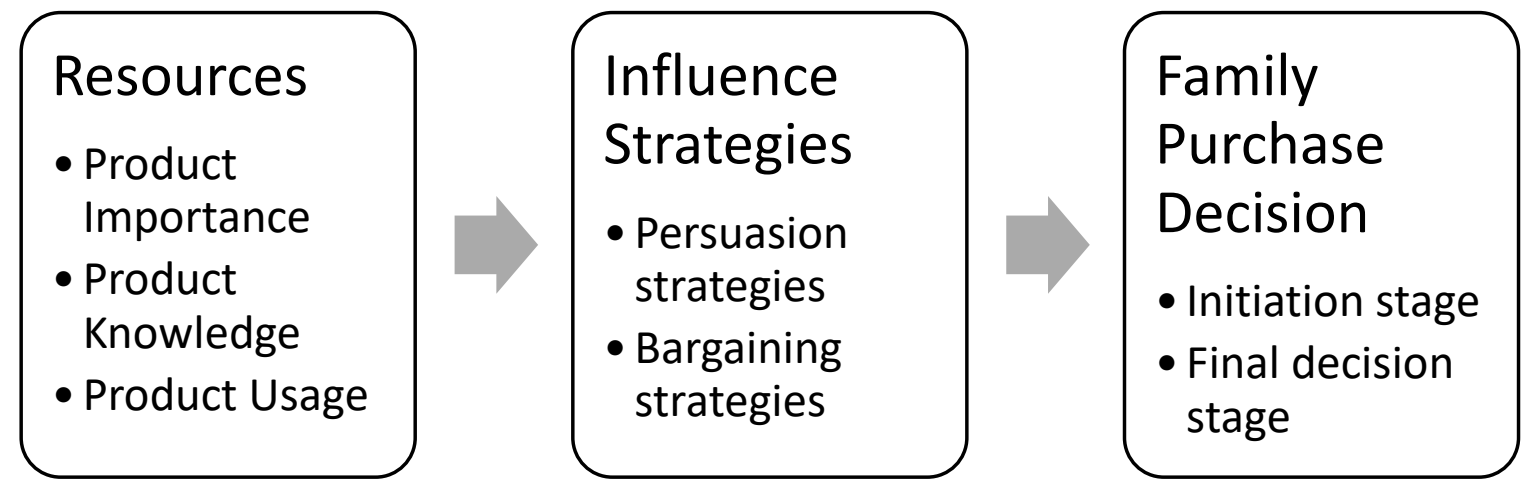

$\mathrm{H} 1$ : Teenagers' product knowledge has a significant effect on family purchase decision

H1a: Teenagers' product knowledge has a significant effect on the initiation stage of the family purchase decision

H1b: Teenagers' product knowledge has a significant effect on the final decision stage of the family purchase decision

H2: Teenagers' product importance has a significant effect on family purchase decision

$\mathrm{H} 2 \mathrm{a}$ : Teenagers' product importance has a significant effect on the initiation stage of the family purchase decision

$\mathrm{H} 2 \mathrm{~b}$ : Teenagers' product importance has a significant effect on the final decision stage of the family purchase decision

H3: Teenagers' product usage has a significant effect on family purchase decision

H3a: Teenagers' product usage has a significant effect on the initiation stage of a family purchase decision

$\mathrm{H} 3 \mathrm{~b}$ : Teenagers' product usage has a significant effect on the final decision stage of the family purchase decision

Teenagers' resources and influence strategies

The findings of previous research on the relationship between the teenager's resources and influence strategies are still questionable (Dikcius et. al, 2018). Foxman et al. (1989a, 1989b) indicated that the importance ratings for the products have marginally significant interaction with the product type and teens reported a more considerable influence for products that were of high importance to them. Beatty and Talpade (1994) also indicated that there was an association between the importance of product category to teens and the perceived relative influence on family purchase decision for durables for the family's and teen's usage. Teenagers tended to exert more significant influence on products that were primarily for their use (Foxman et al., 1988, 1989a). Also, parental coalition strategies were expected to be negatively related to the teenager's influence on family-related purchase decisions (Mangleburg, Grewal \& Bristol, 1999). The discussion, as mentioned earlier, leads the researcher to postulate the following hypotheses: 
INTERNATIONAL JOURNAL OF ACADEMIC RESEARCH IN BUSINESS AND SOCIAL SCIENCES Vol. 10, No. 6, June, 2020, E-ISSN: 2222-6990 @ 2020 HRMARS

H4: Teenagers' product knowledge has a significant effect on influence strategies H4a: Teenagers' product knowledge has a significant effect on persuasion strategies $\mathrm{H} 4 \mathrm{~b}$ : Teenagers' product knowledge has a significant effect on bargaining strategies H5: Teenagers' product importance has a significant effect on influence strategies H5a: Teenagers' product importance has a significant effect on persuasion strategies $\mathrm{H} 5 \mathrm{~b}$ : Teenagers' product importance has a significant effect on bargaining strategies H6: Teenagers' product usage has a significant effect on influence strategies H6a: Teenagers' product usage has a significant effect on persuasion strategies H6b: Teenagers' product usage has a significant effect on bargaining strategies Teenagers' influence strategies and family purchase decision Inconclusive results have been identified regarding the impact of influence strategies on teenagers and family decision-making. Palan and Wilkes (1997) found that active teens' influence strategies duplicated their parents' responses strategies. The most effective strategy used by teens were money deals, reasoning and direct ask. Lee and Collins (2000) discovered that emotion strategy had the most impact on the influence scores of children in a family purchase decision. Lee and Collins (2000) then conjectured that children's use of emotion strategies would result in a more significant influence in family decision-making. This is further supported by Su et.al (2019) who found that four main influence strategies were being exercised by teenagers towards their parents, namely bargaining, direct request, persuasion and emotional strategies. However, Bao (2001) found no significant relationship among influence strategies (i.e. bargaining and persuasion strategies) and family purchase decision.

Contrarily, Marquis (2004) found that there was a significant correlation between interpersonal influence and strategies used by children to influence parental decisions. Also, a strong positive relationship was discovered among environmental influence, interpersonal influence, societal influence and influence strategies used by children towards a parental purchasing decision. Besides, Belch, Belch and Sciglimpaglia (1980) initiated that teenagers used persuasion strategies towards family purchase decision of furniture, television and appliance. Teenagers would also use the combination of influence strategies such as bargaining and persuasion strategies in influencing their family purchase decision. Spiers (2017) revealed that the use of negotiation and direct request are the two main influence strategy exercised by teenagers in family purchase decision of family vacation. The discussion above leads the researcher to postulate the following hypotheses:

$\mathrm{H7}$ : There is a significant relationship between the persuasion strategy used by teens and family purchase decision

H7a: There is a significant relationship between the persuasion strategy used by teens and the initiation stage of the family purchase decision

$\mathrm{H} 7 \mathrm{~b}$ : There is a significant relationship between the persuasion strategy used by teens and the final decision stage of the family purchase decision

H8: There is a significant relationship between the bargaining strategy used by teens and family purchase decision

H8a: There is a significant relationship between the bargaining strategy used by teens and the initiation stage of the family purchase decision

$\mathrm{H} 8 \mathrm{~b}$ : There is a significant relationship between the bargaining strategy used by teens and the final decision stage of the family purchase decision. 
INTERNATIONAL JOURNAL OF ACADEMIC RESEARCH IN BUSINESS AND SOCIAL SCIENCES Vol. 10, No. 6, June, 2020, E-ISSN: 2222-6990 @ 2020 HRMARS

\section{Methodology}

Survey instrument

The survey instrument used was in the form of a structured questionnaire. The original questionnaire was developed in the English Language. However, for this study, questionnaires were prepared and distributed in bilingual form (Malay and English). Bilingual questionnaires were used by the researcher to aid students in understanding and answering the questions provided in the questionnaire. Questionnaires were manually distributed to 700 respondents (students) and collected by the researcher in order to obtain their influence on family purchase decisions Questionnaire Design

The following section will be divided into three sub-sections based on the three variables used in this study. It is an attempt to provide further explanation on the questionnaire, particularly about items, dimensions and scales of measurements used for each variable tested in this study. The structured questionnaire was either self- developed, or constituted an adoption or adaptation of several previous researchers' questionnaires that were related to the study at hand. The measurement instrument is as shown in Table 1 below.

Table 1: Measurement of Instrument

\begin{tabular}{|l|}
\hline Measurement Instrument \\
\hline Family Purchase Decision \\
1. Getting people to realize that a mobile phone is needed \\
2. Realizing that a mobile phone is useful to have \\
3. Getting others to start thinking about buying a mobile phone \\
4. Deciding on the brand/model that was finally purchased \\
5. Deciding on which store to buy the mobile phone from \\
6. Buying the mobile phone from the store \\
\hline Resources \\
1. As compared to my parents, my usage of mobile phone is \\
2. On average, how many hours do you use your mobile phone per day? \\
3. Having a mobile phone is an integral part of my life \\
4. For me, the mobile phone does not matter \\
5. I do not care whether I have a mobile phone or not \\
6. This mobile phone is essential to me \\
7. I must choose a suitable mobile phone for myself \\
8. I am very concerned about the outcome of my choice of mobile phone \\
9. I know a lot about the mobile phone as compared to other family members \\
10. I will make sure that I have some information about the mobile phone before \\
11. I ask my parents to buy it for me \\
12. My knowledge of the mobile phone helps me to understand the technical \\
13. I know a lot about the mobile phone design \\
14. I know a lot about the mobile phone \\
Influence Strategies
\end{tabular}


1. If my parents buy a mobile phone for me, I will offer to pay them back about several Ringgit every month

2. When I am discussing the purchase of a mobile phone with my parents, I will give a reason that makes good sense

3. I will tell my parents that I would look cool having that mobile phone

4. I will keep on telling my parents that I want to buy a mobile phone over and over until they buy it for me

5. I will beg for the mobile phone I want until it makes my parents fed up so that they will buy what I want

6. I will get real pushy and whine for the mobile phone that I want

7. I indicate to my parents the fact that my other friends have a mobile phone

8. I will say that I need a mobile phone and if I do not get it my friends will make fun of me or laugh at me

9. I will tell my parents that friends have mentioned my mobile phone model is out of date, and I need the latest one

10. To persuade my parents to buy a mobile phone, I put on a pity face

11. I will tell my parents that if they buy a mobile phone for my brother/sister, they should buy a mobile phone for me

12. I make my parents feel guilty in the hope to have them buy a mobile phone for me

Family purchase decision

The dependent variable for this study was the family purchase decision. It is hypothesized that the two variables could explain variations in the family purchase decision and comprising of resources and influence strategies. The first question in the questionnaire was a screening question, which was developed to ensure that the respondents owned the product of interest to this study, i.e. the mobile phone. Only respondents who owned mobile phones had to complete the whole questionnaire. The dichotomous question of 'Yes' or 'No' was used in the first question.

The subsequent questions of family purchase decision were in the form of multiple-choice questions which were measured using the modification of the questions by Talpade and Trilokekar-Talpade (1995) about nine items of the teen's influence on the family purchase decision. In the study of Talpade and Trilokekar-Talpade (1995), product type was not included directly in the items. In an attempt to let the respondents obtain a clear picture of the mobile phone, the term 'mobile phone' was included in each of the nine items in the questionnaire used in this study. The nine items were the result of the separation of two stages, i.e. initiation and final decision stages. The initiation stage was a combination of initiation and search/evaluation stage, which comprised of five items. The items included bringing up the idea to buy the product, getting people to realize that this product was needed, realizing that the product would be useful to have, and getting others to start thinking about buying the product. At the decision stage, the items that were included in this study were visiting the store(s), examining the product at the store(s), deciding on the final brand/model, deciding on which store to purchase the product from and purchasing the mobile phone from the store. All the nine items constituted a combination of search and final decision stage where the search stage comprised of a single item of visiting the stores. The final decision stage comprised of four items. The items 
comprised of examining the mobile phone at the store(s), picking it up from the store, deciding on the final brand/model and deciding on which store to purchase the product from.

Talpade and Trilokekar-Talpade (1995) used a seven-point Likert item scale with values ranging from ' 0 ' - 'I did not contribute at all', to ' 7 ' - 'the entire contribution is mine'. However, given the nature of the respondents used in this study which comprised of teens below the age of 18 (i.e. aged 13 to 17 years old) as compared to the samples used in the study of Talpade and Trilokekar-Talpade (1995) where 96 per cent of the teens who respondents in their study were at the ages of 17 and 18 years old, it would be deemed appropriate to use a five-point scale for this study. Besides, the scale used in the questionnaire section of the family purchase decision was also slightly changed based on the feedback received from the pilot study. Thus, for this study, the scale was changed to '1' - 'I did not contribute at all (the whole contribution comes from my parents) until ' 5 ' - 'I contributed (the whole contribution comes from myself)'.

\section{Resources}

The independent variables used in this study were resources. The questionnaire was developed by the researcher and also adapted from those of past researchers. Based on several newly developed questions as well as adoption and adaptation of questions from past researchers, specific questions on the impact of teenager's resources on family purchase decision were formulated. As such, a fivepoint Likert item scale ranging from ' 1 '- strongly disagree' to ' 5 '-strongly agree were developed to measure the teenagers' product importance and product knowledge. Six items were used to measure product importance were based on the adoption of questions from Mittal and Soo-Lee (1988) and Mittal (1989). Six items were used to measure product knowledge, based on the adaptation of questions from the study of Beatty and Talpade (1994) and the study of Kleiser and Mantel (1994). Questions on product usage were either self-developed or adopted using the five-point scale. Questions was based on the study of Beatty and Talpade (1994), which was an attempt to measure the level of the teen's usage of mobile phone as opposed to other members in their family, and the scale ranged from ' 1 '-'Much less than theirs' to '5'- 'Much greater than theirs'.

\section{Influence Strategies}

Both the independent and dependent variables were mediated by the elements of influence strategies, which were treated as mediating variables. Influence strategies measure the extent of strategies used by the teenagers towards family purchase decision, taking into consideration the independent variables used in this study, i.e. resources and demographic characteristics.

The influence strategies (i.e. persuasion and bargaining) items were included in the questionnaire. Several sample items developed by past researchers (Bao; 2001; Palan \& Wilkes; 1997) were either adopted or adapted for this study came from the study of Bao (2001) and Palan and Wilkes (1997). A five-point Likert item scale ranging from ' 1 ' - strongly disagree' to ' 5 '-strongly agree was developed to assess the teenager's influence strategies.

Population and sample size

The following section will discuss the unit of analysis and the sample size employed in this study. The discussion on the unit of analysis and sample size are presented below. 
INTERNATIONAL JOURNAL OF ACADEMIC RESEARCH IN BUSINESS AND SOCIAL SCIENCES

Vol. 10, No. 6, June, 2020, E-ISSN: 2222-6990 @ 2020 HRMARS

\section{Unit of analysis}

This study focused on teenagers (in private academic secondary schools aged 13-17 years old). Therefore, the unit of analysis was individual school-aged teenagers at the ages of 13 to 17 years old. 700 questionnaires (50 respondents $x 14$ schools) were distributed and self-administered by the researcher.

\section{Sampling technique}

Proportionate stratified random sampling was used in this study. Proportionate stratified random sampling is the most efficient sampling among all the probability designs (Sekaran, 2003). By using the proportionate stratified random sampling, the schools were stratified by the state to ensure that each state was represented. Then, the number of schools to be selected in each state was determined based on proportional allocation. Later, the researcher picked the schools in each state randomly. Finally, 50 numbers (which represented 50 students in each school) were randomly picked from the container. The researcher then requested the headmaster to give the questionnaires to those 50 students who fell under the randomly picked number (based on the student's name list).

The proportionate method was used to ensure the equal probability of selection and fair distribution of selected schools in each state. The selection of schools to be covered in this study had to fulfil the following criteria:

1) not known as boarding schools because this study only covered teenagers who lived with their parents in the same house

2) charging school fees of at least RM 2000 (per year) or above per student, thus reflecting that respondents from those types of schools were able to own high-end mobile phones (with a minimum price of RM 500), to suit with the population of this study. In order to confirm that the school fees are at least RM 2000 (per year), the researcher contacted the schools and requested for information on school fees from the school staff. In screening the respondents based on the price of the mobile phones that they owned, the researcher referred to the price of the mobile phones on the mobile telecommunication website.

As such, it was found that only 14 schools fulfilled the criteria above.

\section{Data Analysis}

Analysis of data

Among the statistical tools that were used by previous researchers were the regression analysis (Marquis, 2004; Lee \& Collins, 2000). Thus, for ease of comparison, this study used the statistical tools used by Marquis (2004) and Lee and Collins (2000), which comprised of the regression analysis. The multiple regression analysis was used to test the teenagers' influence in family purchase decision concerning the mobile phone products. Also, the factor analysis and reliability tests were used to determine which independent variables were used for the study at hand.

\section{Discussion}

Descriptive Analysis of Respondents

Out of 700 questionnaires that were distributed to 14 private academic secondary schools in Malaysia, 625 questionnaires (89.29 per cent) were returned by the respondents. Of these 625 questionnaires (89.29 per cent), 512 usable questionnaires (81.92 per cent) were used in this study while the remaining 113 which returned as unusable responses (18.08 per cent) were excluded from 
INTERNATIONAL JOURNAL OF ACADEMIC RESEARCH IN BUSINESS AND SOCIAL SCIENCES Vol. 10, No. 6, June, 2020, E-ISSN: 2222-6990 @ 2020 HRMARS

further analysis of this research. The 113 (18.08 per cent) unusable questionnaires were excluded from this research mainly because the respondents owned a mobile phone priced below RM 500 and they did not answer the essential questions in the questionnaires.

Of the 512 respondents, 21.7 per cent respondents were aged 17 years old, followed by 20.1 per cent respondents aged 16 years old, 19.9 per cent aged 15 years old, 19.7 per cent aged 13 years old and 18.6 per cent aged 14 years old (refer to Table 5.1). With regards to the respondent's gender, it was found that the majority of the respondents were female, i.e. 52.3 per cent, while the remaining 47.7 per cent of the respondents were male. In sum, the distribution was almost equal for the respondents' age and gender. In terms of ethnicity/race, more than half of the total sample, or 68.9 per cent of the respondents were Chinese, followed by Malay (18.2 per cent) and Indians (7.2 per cent) while 5.7 per cent of the respondents belonged to other ethnicities/race (refer Table 2 below).

Table 2: Profile of Respondents

\begin{tabular}{|c|c|c|}
\hline & Frequency & Percent (\%) \\
\hline 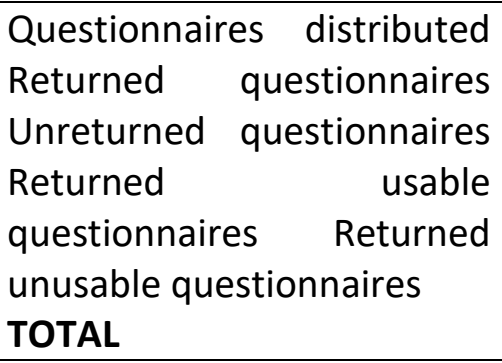 & $\begin{array}{c}700 \\
625 \\
75 \\
512 \\
113\end{array}$ & $\begin{array}{l}100 \\
89.29 \\
10.71 \\
81.92 \\
18.08 \\
100\end{array}$ \\
\hline $\begin{array}{lll}\text { Age } & & \\
13 & \text { years } & \text { old } \\
14 & \text { years } & \text { old } \\
15 & \text { years } & \text { old } \\
16 & \text { years } & \text { old } \\
17 \text { years old } & \\
\text { TOTAL } & \\
\end{array}$ & $\begin{array}{l}101 \\
95 \\
102 \\
103 \\
111 \\
\mathbf{5 1 2} \\
\end{array}$ & $\begin{array}{l}19.7 \\
18.6 \\
19.9 \\
20.1 \\
21.7 \\
100 \\
\end{array}$ \\
\hline $\begin{array}{l}\text { Gender } \\
\text { Male } \\
\text { Female } \\
\text { TOTAL }\end{array}$ & $\begin{array}{l}244 \\
268 \\
512\end{array}$ & $\begin{array}{l}47.7 \\
52.3 \\
100\end{array}$ \\
\hline $\begin{array}{l}\text { Ethnicity/race } \\
\text { Malay } \\
\text { Chinese } \\
\text { Indian } \\
\text { Others } \\
\text { TOTAL }\end{array}$ & $\begin{array}{l}93 \\
353 \\
37 \\
29 \\
512\end{array}$ & $\begin{array}{l}18.2 \\
68.9 \\
7.2 \\
5.7 \\
100\end{array}$ \\
\hline
\end{tabular}

Descriptive Analysis of Major Variables

The dependent variable used for this study was the family purchase decision. Family purchase decision comprised of two stages, i.e. initiation stage and final decision stage. It was found that the initiation stage had a mean value of 3.133 (standard deviation $=1.025$ ) while the final decision stage had a mean value of 3.004 (standard deviation $=1.144$ ). 
INTERNATIONAL JOURNAL OF ACADEMIC RESEARCH IN BUSINESS AND SOCIAL SCIENCES Vol. 10, No. 6, June, 2020, E-ISSN: 2222-6990 @ 2020 HRMARS

Another variable used in this study was the influence strategies. The mean score for the persuasion strategies was 2.27 (standard deviation $=0.936$ ) while the bargaining strategies had a mean score of 3.195 (standard deviation $=0.652$ ). The mean score for emotion strategies was 2.31 (standard deviation $=0.99$ ) while the direct request strategies had a mean score of 2.96 (standard deviation = 1.052).

The independent variables resources which comprised of three variables i.e. product importance $($ Mean $=3.905$, standard deviation $=0.930)$, product knowledge $($ Mean $=3.328$, standard deviation $=$ 0.890 ) and product usage (Mean $=2.950$, standard deviation $=1.133$ ). Based on the mean scores, it was apparent that the majority of the respondents claimed they 'agree' that mobile phone was an important product to them. In terms of product knowledge, most of the respondents indicated their level of agreement between 'neither agree nor disagree' and 'agree'. This shows that the respondents were unsure of their knowledge of the mobile phone.

\section{Factor Analysis on Resources}

The factor analysis with the principal component method was chosen for this study. After conducting the factor analysis, it was found that out of fourteen items of the independent variable used in this study, three items had to be removed. The items that were removed were: 1) I need to choose a suitable mobile phone for myself; 2) I am very concerned about the outcome of my choice of mobile phone, and 3) I will make sure that I have some information about mobile phones before I actually ask my parents to buy one for me. The results of the factor analysis are provided in Table 3 below. Once the number of factors was determined, the factors had to be 'rotated' in order to obtain a clear interpretation of the loadings pattern. For this study, the Varimax rotation method was employed since the approach was the most commonly used, and it tended to be more accessible and clearer to interpret. Besides, the Varimax rotation method could also minimize the number of variables that had high loadings on each factor (Pallant, 2001).

The results of the factor analysis after the Varimax rotation showed a three-factor solution with eigenvalues greater than 1.0 and the total variance explained was 69.304 per cent of the total variance. The KMO measure of the sampling adequacy was 0.857 , indicating sufficient intercorrelations, while Bartlett's Test of Sphericity was significant (Chi-square $=2645.444, p<0.01$ ). Component 1 was then classified as product knowledge, component 2 as product importance and component 3 as product usage. 
INTERNATIONAL JOURNAL OF ACADEMIC RESEARCH IN BUSINESS AND SOCIAL SCIENCES Vol. 10, No. 6, June, 2020, E-ISSN: 2222-6990 @ 2020 HRMARS

Table 3: Result of the factor analysis for Resources

\begin{tabular}{|l|l|l|l|}
\hline & & Component & \\
\hline Items & 1 & 2 & 3 \\
\hline & Product Knowledge & Product Importance & Product Usage \\
\hline Knowledge 1 & 0.721 & & \\
\hline Knowledge 3 & 0.835 & & \\
\hline Knowledge 4 & 0.733 & & \\
\hline Knowledge 5 & 0.811 & & \\
\hline Knowledge 6 & 0.839 & & \\
\hline Importance 1 & & 0.820 & \\
\hline Importance 2 & & 0.860 & \\
\hline Importance 3 & & 0.838 & \\
\hline Importance 4 & & 0.818 & \\
\hline Usage 1 & & & 0.797 \\
\hline Usage 2 & & & 0.771 \\
\hline Eigenvalue & 3.294 & 2.926 & 1.403 \\
\hline $\begin{array}{l}\text { Percentage Variance } \\
\text { (69.304\%) }\end{array}$ & 29.944 & 26.603 & 12.756 \\
\hline
\end{tabular}

\section{Factor Analysis on Influence Strategies}

Factor analysis with the principal component method has been chosen for this study. After conducting the factor analysis, it was found that out of the twenty-one items of the mediator variable used in this study, nine items had to be removed. The results of the factor analysis can be viewed in Table 4. The items that had to be removed were:

1) I try to negotiate something agreeable to both of us (i.e. my parents and I)

2) If I want an expensive mobile phone, I will offer to pay half of the price and request my parents to pay the remaining half

3) I will give logical reasons why I really need a mobile phone

4) If I do not get the mobile phone that I want, I will go to my room, shut the door and ignore my parents

5) When I want a mobile phone, I will act childishly in front of my parents

6) I become especially affectionate to my parents in the hope of getting a mobile phone

7) I need a mobile phone, so I will tell my father/mother that I need a mobile phone severely

8) I want a mobile phone, so I will tell my father/mother that I want

9) I need to tell my parents I want a mobile phone and they will buy it for me.

Once the number of factors was determined, the factors had to be 'rotated' in order to obtain a clear interpretation of the loadings pattern. For the purpose of this study, the researcher used the Varimax rotation method, as this approach was the most commonly used, and it tended to be easier to operationalize and the results allowed for greater clarity of interpretation. Besides, the Varimax rotation method could also minimize the number of variables that had high loadings on each factor (Pallant, 2001).

The results of the factor analysis with the Varimax rotation showed a two-factor solution with eigenvalues greater than 1.0 and the total variance explained was 60.626 per cent of the total 
INTERNATIONAL JOURNAL OF ACADEMIC RESEARCH IN BUSINESS AND SOCIAL SCIENCES Vol. 10, No. 6, June, 2020, E-ISSN: 2222-6990 @ 2020 HRMARS

variance. The KMO measure of sampling adequacy was 0.889 , indicating sufficient intercorrelations while Bartlett's Test of Sphericity was significant (Chi square $=3014.183, p<0.01$ ). The researcher thus classified component 1 as persuasion and component 2 as bargaining strategies.

Table 4: Result of the factor analysis for Influence Strategies

\begin{tabular}{|l|l|l|}
\hline \multirow{2}{*}{ Items } & Component \\
\cline { 2 - 3 } & 1 & 2 \\
\hline & Persuasion Strategies & Bargaining Strategies \\
\hline Influence Strategies 3 & & 0.865 \\
\hline Influence Strategies 4 & & 0.864 \\
\hline Influence Strategies 6 & 0.748 & \\
\hline Influence Strategies 7 & 0.803 & \\
\hline Influence Strategies 8 & 0.774 & \\
\hline Influence Strategies 9 & 0.698 & 0.820 \\
\hline Influence Strategies 10 & 0.738 & 0.860 \\
\hline Influence Strategies 11 & 0.726 & 0.838 \\
\hline Influence Strategies 12 & 0.745 & 0.818 \\
\hline Influence Strategies 14 & 0.704 & \\
\hline Influence Strategies 17 & 0.764 & \\
\hline Influence Strategies 18 & 0.701 & \\
\hline Eigenvalue & 5.488 & 1.788 \\
\hline $\begin{array}{l}\text { Percentage } \\
\text { (60.626\%) }\end{array}$ & & 14.896 \\
\hline
\end{tabular}

Factor Analysis on Family Purchase Decision

Factor analysis with the principal component method was chosen for this study. Based on the results of the factor analysis, it was found that out of the nine items of the dependent variable used in this study, three items had to be removed. The items that were removed were: 1) bring up the idea to buy a mobile phone; 2) visiting the stores to look for different brands/models of mobile phone, and 3) examine the different brands/models of a mobile phone. The results of the factor analysis can be viewed in Table 5.

Once the number of factors was determined, the factors were then rotated using the Varimax Rotation method. The results of the factor analysis showed a two-factor solution with eigenvalues greater than 1.0 and the total variance explained was 67.94 per cent of the total variance. The KMO measure of sampling adequacy was 0.755 , indicating sufficient intercorrelations, while Bartlett's Test of Sphericity was significant (Chi square=931.83, $p<0.01$ ). Component 1 was then classified as the final decision stage and component 2 as the initiation stage, following the same classifications of the stages of Talpade and Trilokekar-Talpade (1995). 
INTERNATIONAL JOURNAL OF ACADEMIC RESEARCH IN BUSINESS AND SOCIAL SCIENCES Vol. 10, No. 6, June, 2020, E-ISSN: 2222-6990 @ 2020 HRMARS

Table 5: Result of the factor analysis for Family Purchase Decision

\begin{tabular}{|l|l|l|}
\hline \multirow{2}{*}{ Items } & Component \\
\cline { 2 - 3 } & 1 & 2 \\
\hline & Final Decision Stage & Initiation Stage \\
\hline FPD 2 & & 0.848 \\
\hline FPD 3 & & 0.776 \\
\hline FPD 4 & & 0.745 \\
\hline FPD 7 & 0.688 & \\
\hline FPD 8 & 0.862 & \\
\hline FPD 9 & 0.880 & 1.990 \\
\hline Eigenvalue & 2.086 & 33.168 \\
\hline $\begin{array}{l}\text { Percentage } \\
\text { (67.94\%) }\end{array}$ & 34.773 & \\
\hline
\end{tabular}

Reliability Analysis results for resources, influence strategies and family purchase decision.

The rule of thumb outlined by Pallant (2001) indicated that the well-validated scales should have a Cronbach alpha coefficient value of 0.7 and above, while Hair, Anderson, Tatham, and Black (1998) indicated that the Cronbach alpha coefficient of 0.6 was reliable for exploratory analysis. The reliability analysis conducted for the independent variable in this study showed reliable results for product knowledge (Cronbach alpha coefficient $=0.864$ ), product importance (Cronbach alpha coefficient $=0.883$ ) and product usage (Cronbach alpha coefficient $=0.513$ ). The value of Cronbach alpha for both the product knowledge and product importance fulfilled the rule of thumb outlined by Hair et al. (1998) and Pallant (2001).

In contrast, the value of the Cronbach alpha coefficient for product usage was below 0.7 , which may be caused by the short scale (i.e. scale with fewer items for product usage). Nunnaly (1967) and Kerlinger and Lee (2000) suggested that, in some cases, a reliability value of 0.5 to 0.6 was acceptable. In addition to that, Briggs and Cheek (1986) suggested looking for the value of inter-item correlation, with a suggested optimal range of 0.2 to 0.4 . The inter-item correlation for product usage was 0.345 , and the value of the Cronbach alpha of product usage of 0.5 also fulfilled the rule of thumb outlined by Nunnaly (1967) and Kerlinger and Lee (2000). This proves that the Cronbach alpha of 0.5 for product usage fulfils the optimal range and that the scale for product usage was well validated.

The reliability analysis conducted for the mediator variable in this study showed favourable results for persuasion strategies (Cronbach alpha coefficient $=0.908$ ) and bargaining strategies (Cronbach alpha coefficient $=0.747$ ). The value of the Cronbach alpha for both the persuasion and bargaining strategies fulfilled the rule of thumb outlined by Hair et al. (1998) and Pallant (2001).

Finally, the reliability analysis conducted for the dependent variable in this study showed that the initiation stages of family purchase decision obtain a Cronbach alpha coefficient of 0.739 and the final decision stages gained a Cronbach alpha coefficient of 0.779 . The values of the Cronbach alpha for both the stages of family purchase decision fulfilled the rule of thumb outlined by Hair et al. (1998) and Pallant (2001). 
INTERNATIONAL JOURNAL OF ACADEMIC RESEARCH IN BUSINESS AND SOCIAL SCIENCES Vol. 10, No. 6, June, 2020, E-ISSN: 2222-6990 @ 2020 HRMARS

Table 6: Reliability Analysis results for resources, influence strategies and family purchase decision.

\begin{tabular}{|l|l|l|l|}
\hline Variable & Number of Items & Items Dropped & Cronbach Alpha \\
\hline Resources & & - & \\
\hline Product Knowledge & 5 & - & 0.864 \\
\hline Product Importance & 4 & - & 0.883 \\
\hline Product Usage & 2 & - & 0.513 \\
\hline Influence Strategies & & - & \\
\hline Persuasion & 10 & - & 0.908 \\
\hline Bargaining Purchase & 2 & - & 0.747 \\
\hline $\begin{array}{l}\text { Family } \\
\text { Decision }\end{array}$ & 3 & - & \\
\hline Initiation Stage & 3 & - & 0.739 \\
\hline Final Decision Stage & & - & 0.779 \\
\hline
\end{tabular}

Validity

The validity assessment recommended by Hair et al. (1998) was used for this study. The validity assessment is shown in the following section:

\section{Content validity}

Content validity was assessed to ensure that there was an association between the items and its conceptual definition (Hair et al., 1998). Based on the feedback obtained from the pilot test on the forty respondents of one of the private school in Selangor, several amendments to the questionnaire were made, resulting in improvement in content validity.

\section{Multiple Regression Analysis}

This section presents the analyses of multiple regression on significant variables used in this research. The multiple regression analyses were conducted to determine the relationship between variables.

\section{Relationship between resources and family purchase decision}

Multiple regression analyses were conducted between resources and family purchase decision (as

shown in Table 7 below). For the initiation stage of family purchase decision, it was found that the $\mathrm{R}^{2}$ was 0.262 indicating that all the six variables explained 26.2 per cent of the variance in the initiation stage of the family purchase decision. The model was significant $(F=29.850, p<0.01)$. A closer examination revealed that product usage $(\beta=0.075, p<0.10)$, product importance $(\beta=0.348, p<$ $0.01)$, and product knowledge $(\beta=0.224, p<0.01)$ were positively related to the initiation stage of family purchase decision.

Looking at the final decision stage of family purchase decision (refer to Table 5.8), it was discovered that the $R^{2}$ was 0.250 indicating that 25 per cent of the variance in final decision stage of family purchase decision was explained by all the three variables and the model was significant $(F=28.128$, $p<0.01)$. A closer examination revealed that product usage $(\beta=0.109, p<0.01)$, product importance $(\beta=0.197, p<0.01)$, and product knowledge $(\beta=0.295, p<0.01)$ were positively related to the final decision stage of family purchase decision. Therefore, hypotheses H1a), H1b), H2a), H2b) and H3a) \& $\mathrm{H} 3 \mathrm{~b})$ were fully supported.

The significant positive relationships were found among all three components of resources (i.e. product knowledge, product usage and product importance) and in both the stages of family 
INTERNATIONAL JOURNAL OF ACADEMIC RESEARCH IN BUSINESS AND SOCIAL SCIENCES Vol. 10, No. 6, June, 2020, E-ISSN: 2222-6990 @ 2020 HRMARS

purchase decision (i.e. initiation stage and final decision stage). The results indicated that teenagers who had more product knowledge, product importance and product usage had the full extent of influence in the family purchase decision of mobile phones for their use, as compared to their counterpart (i.e. parents).

As such, with regards to technological items such as mobile phones, teenagers are being perceived by their parents to be more knowledgeable, treating the mobile phone as an essential item and using it more frequently as compared to by their parents. Due to that, parents fully trust their teenage child to decide on the purchase of a mobile phone (Brazil, 1999; McNeal, 1992; Ying, 2003). The finding was consistent with the resource theory of Blood and Wolfe (1960). The results of this study also reflected that in the Malaysian scenario, Malaysian teenagers were found to be the second-highest users of the mobile phones, with 12.3 per cent in the year 2004 (Malaysian Communications and Multimedia Commission, 2004; Yapp \& Khalid, 2006) and 13.1 per cent in the year of 2005 (Malaysian Communications and Multimedia Commission, 2005).

Table 7: Results of the Multiple Regression Analyses Between Resources and Family Purchase Decision (initiation and final decision stages)

\begin{tabular}{|l|l|l|}
\hline \multirow{2}{*}{ Variable } & Standardized Beta \\
\cline { 2 - 3 } & Initiation Stage & Final decision stage \\
\hline Product Usage & $0.075^{*}$ & $0.109^{* * *}$ \\
\hline Product Importance & $0.348^{* * *}$ & $0.197^{* * *}$ \\
\hline Product Knowledge & $0.224^{* * *}$ & $0.295^{* * *}$ \\
\hline F Value & $29.850^{* * *}$ & $28.128^{* * *}$ \\
\hline $\mathrm{R}^{2}$ & 0.262 & 0.250 \\
\hline Adjusted $\mathrm{R}^{2}$ & 0.253 & 0.242 \\
\hline
\end{tabular}

${ }^{*} \mathrm{p}<0.10, * * p<0.05, * * * p<0.01$

\section{Relationship between resources and influence strategies}

Multiple regression analyses were conducted between resources and influence strategies. It can be seen that the $R^{2}$ was 0.125 , indicating that all the three variables explained 12.5 per cent of the variance in persuasion strategies and the model was significant $(F=12.072, p<0.01)$. A closer examination revealed that product importance $(\beta=0.168, p<0.01)$ and product knowledge $(\beta=$ $0.218, p<0.01$ ) were positively related to persuasion strategies.

In contrast, when looking at the relationship between resources and bargaining strategies, it was found that only product importance $(\beta=0.249, p<0.01)$ and product knowledge $(\beta=0.100, p<0.05)$ were positively related to the bargaining strategies. The results showed that the $R^{2}$ was 0.085 , indicating that 8.5 per cent of the variance in the bargaining strategies as explained by all the three variables and the model was significant ( $F=7.843, p<0.01)$. Thus, hypotheses $\mathrm{H} 4 \mathrm{a}$ ) $\mathrm{H} 4 \mathrm{~b}$ ), $\mathrm{H} 5 \mathrm{a}$ ) and $\mathrm{H} 5 \mathrm{~b})$ were fully supported while $\mathrm{H6a}$ ) and $\mathrm{H6b}$ ) were not supported.

The results indicated that knowledgeable teenagers who perceived high importance towards the mobile phone were more successful in using both types of influence strategies. One possible reason for this finding is that, concerning the technological products such as the mobile phone, Malaysian 
INTERNATIONAL JOURNAL OF ACADEMIC RESEARCH IN BUSINESS AND SOCIAL SCIENCES Vol. 10, No. 6, June, 2020, E-ISSN: 2222-6990 @ 2020 HRMARS

teenagers have better skills than their parents, which results in the ability of these teenagers to be successful in exercising both the types of influence strategies towards their parents. The findings of this study supported the resource theory (Blood \& Wolfe, 1960) and the study of Beatty and Talpade (1994) but slightly contradicted with the findings of Foxman et al. (1989a) who found a marginally significant relationship between the teenagers' product importance and the types of relative influence. However, the study of Beatty and Talpade (1994) and Foxman et al. (1989a) only covered the impact of resources on the relative influence but did not specifically cover the relationship between resources and influence strategies.

On the other hand, there was no significant relationship between the teenagers' product usage and influence strategies (i.e. persuasion strategies and bargaining strategies). One possible reason for such an insignificant finding is that parents show an indifferent attitude towards the teenagers' usage of mobile phones, which results in the inability of these teenagers to influence their parents. The results of this study contradicted that of the study of Foxman et al. (1988, 1989a) (refer Table 8 below).

Table 8: Results of the Multiple Regression Analyses Between Resources and Influence Strategies (persuasion and bargaining strategies)

\begin{tabular}{|l|l|l|}
\hline \multirow{2}{*}{ Variable } & Standardized Beta \\
\cline { 2 - 3 } & Persuasion strategies & Bargaining strategies \\
\hline Product Usage & 0.062 & -0.037 \\
\hline Product Importance & $0.168^{* * *}$ & $0.249 * * *$ \\
\hline Product Knowledge & $0.218^{* * *}$ & $0.100^{* * *}$ \\
\hline F Value & $12.072^{* * *}$ & $7.843^{* * *}$ \\
\hline $\mathrm{R}^{2}$ & 0.125 & 0.085 \\
\hline Adjusted $\mathrm{R}^{2}$ & 0.115 & 0.074 \\
\hline
\end{tabular}

${ }^{*} \mathrm{p}<0.10, * * \mathrm{p}<0.05, * * * p<0.01$

\section{Relationship between influence strategies and family purchase decision}

The multiple regression analyses were conducted between influence strategies and family purchase decision. Referring to Table 9, it can be viewed that the $\mathrm{R}^{2}$ was 0.158 indicating that 15.8 per cent of the variance in initiation stage was explained by the two variables and the model was significant $(F=47.925, p<0.01)$. A closer examination revealed that persuasion strategies $(\beta=0.357, p<0.01)$ and bargaining strategies $(\beta=0.199, p<0.01)$ were positively related to the initiation stage.

In contrast, when looking at the relationship between influence strategies and the final decision stage of family purchase decision (refer to Table 9), it was found that only persuasion strategies $(\beta=0.259$, $\mathrm{p}<0.01$ ) was positively related to the final decision stage. The results also showed that the $R^{2}$ was 0.067, indicating that 6.7 per cent of the variance in final decision stage was explained by the two variables and the model was significant ( $F=18.323, p<0.01)$. Thus, hypotheses $\mathrm{H7a}$ ), H7b) and $\mathrm{H} 8 \mathrm{a}$ ) were fully supported while H8b) was not supported.

Multiple regression analyses were conducted to see whether there was any relationship between influence strategies and family purchase decision. Based on that, it was found that there was a 
INTERNATIONAL JOURNAL OF ACADEMIC RESEARCH IN BUSINESS AND SOCIAL SCIENCES Vol. 10, No. 6, June, 2020, E-ISSN: 2222-6990 @ 2020 HRMARS

significant positive relationship between persuasion strategies and both the stages of family purchase decision (i.e. initiation stage and final decision stage). Teenagers were able to exercise their persuasion strategies to a full extent in family purchase decision due to their parents' concern on their desire to own a mobile phone (Bao, 2001). The findings of this research were in accord with those of the studies of Bao (2001) and Belch, Belch and Sciglimpaglia (1980).

It was also found that there was a significant positive relationship between the bargaining strategy and the initiation stage of a family purchase decision. This may be attributed to the parental requests that the children were willing to fulfil for their respective parents. The result somewhat supported the studies of Bao (2001) and Palan and Wilkes (1997), who found a significant relationship between bargaining strategies and family purchase decision. However, the study of Bao (2001) and Palan and Wilkes (1997) did not specify the extent of the family purchase decision that was successfully influenced by these teenagers through the use of the bargaining strategies. Insignificant results were found between bargaining strategy and the final decision stage of the family purchase decision. One possible reason for this insignificant result is that the teenagers' willingness to fulfil their parents' request (in the initiation stage of family purchase decision) made their parents feel obliged to fulfil their teenage children's request, in an attempt to avoid hurting the feelings of their children (Bao, 2001). In the final decision stage of the family purchase decision, the bargaining situation no longer existed between parents and their teenage children.

Table 9: Results of the Multiple Regression Analyses Between Influence Strategies (persuasion and bargaining strategies) and Family Purchase Decision (Initiation and final decision stage)

\begin{tabular}{|l|l|l|}
\hline \multirow{2}{*}{ Variable } & Standardized Beta \\
\cline { 2 - 3 } & Initiation stage & Final decision stage \\
\hline Persuasion strategies & $0.343^{* * *}$ & $0.259^{* * *}$ \\
\hline Bargaining strategies & $0.186^{* * *}$ & 0.009 \\
\hline $\mathrm{F}$ Value & $47.925^{* * *}$ & $18.323^{* * *}$ \\
\hline $\mathrm{R}^{2}$ & 0.158 & 0.067 \\
\hline Adjusted $\mathrm{R}^{2}$ & 0.155 & 0.063 \\
\hline
\end{tabular}

$* p<0.10, * * p<0.05, * * * p<0.01$

\section{Conclusion}

To conclude, this research provided meaningful information on teenagers' resources and the influence strategies used by teenagers towards the family purchase decision. Specifically, the findings of this study discovered that there were significant positive relationships among all three components of resources (i.e. product knowledge, product usage and product importance) and in both the stages of family purchase decision (i.e. initiation stage and final decision stage). In addition, it was also discovered that knowledgeable teenagers who perceived high importance towards the mobile phone were more successful in using both types of influence strategies, while teenager's product usage did not have any effect on influence strategies exercised by these teenagers towards their parents. On top of that, it was also found that it was found that there was a significant positive relationship between persuasion strategies and both the stages of family purchase decision (i.e. initiation stage and final decision stage), and teenagers were able to exercised bargaining strategies in the initiation stage of family purchase decision only. The bargaining strategies was no longer 
effective in the final decision stage of the family purchase decision between parents and their teenage children. These findings enabled the researcher to identify the predictors of family purchase decision as well as provide a better understanding of the teenagers' influence on their family's purchase decision in order to get their desired mobile phones.

The findings of this study indicated that Malaysian teenagers who had more product knowledge, product importance and product usage were able to influence the family purchase decision to a full extent in order to get their desired products. The study has shown that the influence that these Malaysian teenagers had towards their family purchase decision must not be belittled. Finally, the teenagers' voice is heard by their parents. Indirectly, the results of this study also implied that Malaysian parents trusted the family purchase decision made by their teenaged children due to the resources that these teenagers acquired, i.e. product knowledge, product importance and product usage.

Finally, it can be concluded that the findings of this research have shown that all the objectives of this research were answered. This research had also posed some interesting findings that could be used for further research, thus contributing to theory, literature, methodology, and practical aspects in the area of consumer behaviour generally and family research specifically. In summary, the findings of this study indicated that the Malaysian teenagers' resources and influence strategies had a significant effect (to a certain extent) towards the family purchase decision.

\section{Contributions of the Research}

There are three types of contributions expected from this study, namely contribution to theory, literature and methodoogy and practical contribution. The contributions are discussed in the following section.

\section{Contributions to Theory}

The development of the resource theory by Blood and Wolfe (1960) mainly covered the resources used by the husbands and wives in their family. However, the resource theory does not cover the influence of children (i.e. teenagers) in the family. Thus, this research has gone a step further by focusing on the teenagers' resources affecting teenagers' influence in a family purchase decision. This will provide a new avenue for future researchers who are interested to focus on the resource theory (Blood \& Wolfe, 1960) in their study.

The origin of the resource theory (Blood \& Wolfe, 1960) provides several types of resources that could influence the spouses' decision-making in their married lives. These resources include skills (i.e. knowledge). The resource theory treated knowledge as essential resources in influencing decisionmaking (refer to Figure 6.1, pp. 143). The existence of other types of resources, such as usage and perception of importance have not been covered in the resource theory. However, this has been addressed by the researcher in the present study. Based on the results of this study, it was found that the teenagers' resources (i.e. product knowledge, product importance and product usage), and the use of the bargaining and persuasion strategies had significantly affected both the stages of the family purchase decision. The results of this study were in line with the resource theory, which stated that those who had more resources exerted more influence in the family. This shows that the inclusion of these additional types of resources has enhanced the use of resource theory in the area of family research studies. 


\section{Contribution to Literature}

Majority of the previous researches have extensively covered teenagers' relative influence on family purchase decision (Bao, 2001; Belch et al., 1985; Belch et al., 1980; Foxman et al., 1989a, Shoham \& Dalakas, 2003; 2005; Wang et al., 2007). However, the literature that focused on how teenagers influenced their family purchase decision, i.e. influence strategies (Bao, 2001; Belch et al., 1980; Lee \& Collins, 2000; Mangleburg et al., 1999; Palan \& Wilkes, 1997) were still lacking.

Also, the impact of resources on the teenagers' influence on family purchase decision has not been adequately covered previously. This aspect was: 1 ) examined in the perspectives different from that of the study at hand, such as teenagers' employment earnings (Foxman et al., 1989a); on 2) limited in scope, such as concerning the teenagers' product knowledge (Beatty \& Talpade, 1994; Foxman et al.,1989a), product importance (Beatty \& Talpade, 1994; Foxman et al.,1989a) and product usage (Beatty \& Talpade, 1994); or 3) ignored by previous researchers.

From the Malaysian context, there were no records of specific studies that addressed the influences of the Malaysian teenagers towards family purchase decision, particularly regarding variables of the teenagers' resources and influence strategies. Due to that, there is a need to study the influence of Malaysian teenagers towards the family purchase decision.

Finally, although many studies in family research have been done in the past, their main focus was on understanding spousal (husband and wives) decision-making (Commuri \& Gentry, 2000). This notion holds true when several researchers (such as Davis, 1970; Delener, 1994; Henthorne et al., 1997; Hopper, 1995; Martinez \& Polo, 1999; Qualls, 1982; Sidin et al., 2004; Spiro, 1983; Stafford et al., 1996) seem to be concerned of the impact of spouse decision making in purchasing household products.

The misleading use of the term 'family' shows the lack of knowledge and understanding of family research as a whole, and family purchase decision specifically. When referring to the term 'family purchase decision', most of us perceive a decision made by parents for the family and ignore the pester power. It must be noted that teenagers, to some extent, are able to influence family purchase decision (Beatty \& Talpade, 1994; Chavda et al., 2005; Foxman et al., 1989a; Foxman et al., 1989b; Lee \& Collins, 2000; Lee \& Marshall, 1998; Palan \& Wilkes, 1997; Shoham \& Dalakas, 2003). Thus, for this study, the researcher had conceptualized the term family purchase decision. The influence of teenagers on family purchase decision had been operationalized as the extent of purchase decision in the family which was determined by teenagers with the consent of their parents. This operationalization of the abovementioned term is hoped to provide a better insight into the understanding of family research in the future.

\section{Contribution to Methodology}

The first contribution to methodology refers to the use of a structured questionnaire to objectively obtain a better insight into a wide range of issues about the study. A previously available multi-item scale questionnaire specifically covered both the family's and teens' influence on family purchase decision (Talpade \& Trilokekar-Talpade, 1995). However, their study focused on college freshmen teens' segment (i.e. teenagers at the ages of 17 to 18 years old). Following the recommendations 
INTERNATIONAL JOURNAL OF ACADEMIC RESEARCH IN BUSINESS AND SOCIAL SCIENCES Vol. 10, No. 6, June, 2020, E-ISSN: 2222-6990 @ 2020 HRMARS

made by Talpade and Trilokekar-Talpade (1995), for this study, the researcher adopted their questionnaire and extended it to the school-aged teenagers (teenagers at the ages of 13 to 17 years old).

The inclusion of items on influence strategies in the questionnaire was based on the study of Palan and Wilkes (1997) and Bao (2001). The adaptation of such items from the qualitative study (i.e. personal interviews) of Palan and Wilkes (1997) into the present quantitative study provided a new dimension in the field of the family purchase decision. There is hitherto no specific questionnaire developed to measure influence strategies from the perspective of consumer behaviour generally and family purchase decision specifically. For example, previous studies such as that of Palan and Wilkes (1997) provided some examples of the several types of influence strategies in the form of personal interviews. The doctoral dissertation of Bao (2001) was the first attempt to develop a multiitem scale for questionnaires to measure influence strategies. However, Bao (2001) covered influence strategies such as bargaining, reasoning, nagging and showing temper while this study encompassed persuasion, bargaining, emotion and direct request strategies. Besides, Bao (2001) used the same set of questions on the influence strategies to measure the influence strategies exercised by both the teenagers and their parents, using a 7-point Likert scale, which may have created some difficulties for the teenagers.

In contrast, for this study, researcher combined (i.e. adopted and adapted) the studies of both Palan and Wilkes (1997) and Bao (2001) to develop a multi-item scale of the questionnaire with a 5-point Likert scale that specifically focused on the teenagers' influence strategies in a family purchase decision. This would make it easier for the teenaged respondents to answer the questionnaires on the influence strategies, thus resulting in a higher response rate among them. This represents a new departure from the previous methodology of assessing influence strategies of teenagers from the perspectives of consumer behaviour.

Also, there has been no specific questionnaire developed to measure the impact of the teenagers' non-financial resources on the family purchase decision. Thus, based on several self-developed items, adoption and adaptation from previous researches, specific questionnaires of teenagers' nonfinancial resources have been developed. Although several adoptions (Beatty \& Talpade, 1994; Mittal \& Soo-Lee, 1988) and adaptations (Beatty \& Talpade, 1994; Kleiser \& Mantel, 1994; Mittal, 1989) from past researches were made in the process of developing this specific questionnaire, the directions of the previous questionnaires differed from those of the study at hand.

\section{Practical Contribution}

About the practical contribution, this study provided a practical contribution to the relevant organizations, marketing practitioners and advertisers. Practically, the understanding of buyer psychology helps marketers to cater to the right market at the right time and place. The understanding of this issue helps marketers and advertisers to design effective promotional campaigns for the right product and audience. Marketers may wish to direct their promotional campaign messages regarding decision making to family members who dominate a particular part in family purchase decision (Lee \& Collins, 2000). Wimalasiri (2004) further stressed that marketers must look into who has the real "say" in the family purchase decision in order to target their 
INTERNATIONAL JOURNAL OF ACADEMIC RESEARCH IN BUSINESS AND SOCIAL SCIENCES Vol. 10, No. 6, June, 2020, E-ISSN: 2222-6990 @ 2020 HRMARS

marketing strategies appropriately. Based on this study, it was found that teenagers were becoming the new authority when it came to technological know-how and applications (Spero \& Stone, 2004). The findings of this study proved that Malaysian teenagers were able to influence the family purchase decision to the full extent (i.e. the final decision stage of family purchase decision) especially when the products were for their consumption (i.e. self-use products). Noting this, the marketers who are interested in marketing their products in Malaysia must direct their marketing strategies to the teenagers' market since Malaysian teenagers have more say in the family purchase decision, especially when it involves products for the teenagers' self-consumption.

The second practical contribution relates to the resources used in this study. The findings of this study provide a practical contribution to the marketers, whereby, the study helps to increase the understanding of the marketing concept, which is crucial in determining the needs and wants in the markets through the customers' satisfaction (Kotler \& Armstrong, 1996). As such, the more marketers understand their customers, the higher the customer satisfaction. This study found that Malaysian teenagers' resources (i.e. product knowledge, product importance and product usage) had a significant effect in both stages of the family purchase decision. From there, marketers and advertisers in Malaysia will be able to use the findings of this study to strategize their company's marketing plans towards the teenagers' market. For example, knowing that Malaysian teenagers' product knowledge, product usage and product importance have a significant effect on the family purchase decision, marketers and advertisers need to provide more information on the company's product (i.e. product specification, availability of the product's model and retail outlets to purchase the product), thus increasing teenagers' knowledge on the products.

Realizing that the Malaysian teenagers' product importance, product usage and product knowledge have an essential effect on the final stage of the family purchase decision, advertisers should use this information in delivering their message to their consumers. For example, an advertising message which describes children who have these resources should also encourage them to participate actively in the final stage of the family purchase decision (i.e. deciding the brands or model of a product and outlet to buy such products).

The third contribution refers to the effects of influence strategies. In designing the marketing communication programme, marketers and advertisers need to consider that both the parents and children prefer to watch advertisements that resemble their real lives (Bao, 2001). Thus, in the advertised message targeted to the Malaysian market, marketers may highlight the importance of applying both the persuasion and bargaining strategies to initiate family purchase decision, and applying more persuasion strategies in talking to the parents especially in deciding the brand or model of a product and the outlet to buy such a product.

The final contribution refers to the mobile phone products selected for this study. As noted in this study, the mobile phone is categorized as a shopping goods product. The purchase of the mobile phone (i.e. technological products) requires consumers to practice extensive decision-making (McDaniel et al., 2007). As such, marketers should promote mobile phone products in great and informative ways. The advertisements to the target market should comprise information that Malaysian consumers need to make the purchase decision, i.e. the benefits and specific advantages 
INTERNATIONAL JOURNAL OF ACADEMIC RESEARCH IN BUSINESS AND SOCIAL SCIENCES

Vol. 10, No. 6, June, 2020, E-ISSN: 2222-6990 @ 2020 HRMARS

of owning the product. As such, in the context of Malaysia, marketers and advertisers should highlight the specifications of the mobile phone such as high memory storage, availability of the latest version of internet connection and high camera resolution. The availability of this information helps Malaysian consumers in deciding to purchase their desired mobile phones.

\section{References}

Abdul Rahman, M. K. (2003). An examination of familial characteristics and it's effects on children consumption attitude, behavior intention and purchase behavior outcome pattern: The case of Malaysia. Universiti Putra Malaysia.

Assael, H. (1990). Marketing: Principles and Strategy (1st ed.): The Dryden Press.

Assael, H. (1998). Consumer behavior and marketing action (6th ed.). Cincinnati, Ohio: South Western College Publishing

Bansal, R. (2004). Buying Power: A new face of youth consumerism. Business World. June 28

Bao, Y. (2001). Effects of Parental Style and Power on Adolescent's Influence in Family Consumption Decisions [Electronic Version]. Doctoral Dissertation, Doctor of Philosophy in Business (Marketing), 206. Retrieved April 26th from scholar.lib.vt.edu/theses/available/.../unrestricted/Etd.pdf

Beatty, S. E., \& Talpade, S. (1994). Adolescent influence in family decision making: A replication with extension. Journal of Consumer Research, 21, pp. 332-341

Becker, A. (2005). What a Teen Wants. Broadcasting \& Cable, 135(10), pp.16.

Belch, G. E., Belch, M. A., \& Ceresino, G. (1985). Parental and teenage child influences in family decision making. Journal of Business Research, 13, pp.163-176

Belch, M. A., Belch, G. A., \& Sciglimpagia, D. (1980). Conflict in family decision making:An exploratory investigation. Advances in Consumer Research, 7(1), pp. 475-479.

Berg, E., Mo“rtberg, C., \& Jansson, M. (2005). Emphasizing technology: sociotechnical implications. Information Technology \& People, 18(4), pp. 343-358.

Blood, R. O. Jr., \& Wolfe, D. M. (1960). Husbands and Wives: The dynamics of married living. Glencoe, IL: Free Press

Brazil, J. (1999). Play dough. American Demographics, 21(12), pp. 56-61.

Bressler, D. (2006). Mobile Phones: A New Way To Engage Teenagers In Informal Science Learning [Electronic Version], 19. Retrieved 10th March 2008 from http://www.archimuse.com/mw2006/papers/bressler/bressler.html.

Briggs, S. R., \& Cheek, J. M. (1986). The role of factor analysis in the development and evaluation of personality scales. Journal of Personality, 54, pp.106-148.

Chaplin, L. N., \& John, D. R. (2005). Materialism in Children and Adolescents: The Role of the Developing Self-Concept. Advances in Consumer Research, 32, pp. 219-221.

Chavda, H., Haley, M., \& Dunn, C. (2005). Adolescents' influence on family decision making. Young Consumers, Quarter 2, pp.68-78

China Women's Daily, in Ying, G. (2003). Consumption Patterns of Chinese Children. Journal of Family and Economic Issues, 24(4), pp. 373-379.

Commuri, S., \& Gentry, J. W. (2000). Opportunities of family research in marketing. Academy of Marketing Science Review, 2000(8), pp. 1-34

Cora, H. (2019). The Effects of Caharcteristics of Generation Z on 21st Century Business Strategies. Kafkas Üniversitesi Iktisadi ve Idari Bilimler Fakültesi Dergisi, 10(20), 909-926. 
INTERNATIONAL JOURNAL OF ACADEMIC RESEARCH IN BUSINESS AND SOCIAL SCIENCES

Vol. 10, No. 6, June, 2020, E-ISSN: 2222-6990 @ 2020 HRMARS

Davis, H. L. (1970). Dimensions of marital roles in consumer decision making. Journal of Marketing Research (pre-1986), Vol. 7, pp. 168-177

Delener, N. (1994). Religious contrasts in consumer decision behavior patterns: Their dimensions and marketing implications. European Journal of Marketing, 28(5), pp.36-53.

Dikčius, V., Pikturnienè, I., Pakalniškienè, V., Reardon, J., \& Šeimienė, E. (2018). Adolescent Influence on Parental Purchase Decisions: Typology of Innovative Products. Market-Tržište, 30(1), 2339.

Dobrow, L. (2006). Teen Angel? Kinda. Advertising Age, 77(1), pp.14.

Duh, H. I., \& Iyiola, O. (2020). Explaining clothing decision-making styles among South-African and Nigerian young adults using two life-course theories. Journal of Fashion Marketing and Management.

Flurry, L. A. (2007). Children's influence in family decision-making: Examining the impact of the changing American family. Journal of Business Research 60, pp. 322-330.

Foxman, E. R., \& Tansuhaj, P. S. (1988). Adolescents' and mothers' perceptions of relative influence in family purchase decisions: Patterns of agreement and disagreement. Advances in Consumer Research, 15, pp. 449-453

Foxman, E. R., Tansuhaj, P. S., \& Ekstrom, K. M. (1989a). Adolescents' Influence In Family Purchase Decisions: A Socialization Perspective Journal of Business Research, 18, pp. 159-172.

Foxman, E. R., Tansuhaj, P. S., \& Ekstrom, K. M. (1989b). Family members' perceptions of adolescencents' influence in family decision making. Journal of Consumer Research, 15, pp.482-491

Geser, H. (2004). Towards a sociological theory of mobile phone [Electronic Version]. May, 1-47. Retrieved on 10th March 2008 from http://socio.ch/mobile/t_geser1.pdf.

Hair, J. E., Anderson, R. E., Tatham, R. L., \& Black, W. C. (1998). Multivariate Data Analysis (Fifth ed.): Prentice-Hall International Inc., Upper saddle River, New Jersey

Henthorne, T., L, LaTour, M., S, \& Hudson, T., W (1997). Japanese couples' marital roles in stages of product purchase decision making. International Marketing Review, 14(1), pp. 39-58.

Hopper, J. S. (1995). Family financial decision making: implications for marketing strategy. Journal of Services Marketing, 9(1), pp. 24-32.

Johnson, B. (2006). Connected and craving: Teens hungry for latest cellphone technology. Advertising Age, 77(12), pp. 1.

Kaur, A., \& Medury, Y. (2011). Impact of The Internet on Teenager's Influence on Family Purchases. Young Consumers, 12(1), 27-38.

Kerlinger, F. M., \& Lee, H. (2000). Foundations of Behavioral Research (Fourth ed.): Stamford: Wadsworth.

Kleiser, S.B. \& Mantel, S.P. (1994). The Dimensions of Consumer Expertise: A Scale Development. In Ravi Achrol and Andrew Mitchell, 1994, AMA Summer

Educators' Proceedings, 5, American Marketing Association, Chicago, pp. 20-26

Kotler, P., \& Armstrong, G. (1999). Principles of Marketing (7th Edition ed.): Prentice Hall International Inc.

Krejcie, R. V., \& Morgan, D. W. (1970). Determining sample size for research activities. Educational and Psychological Measurement, 30, pp. 607-610.

Lasica, J. D. (2007). The Mobile Generation: Global Transformations at the Cellular Level. Washington, DC: The Aspen Institute. 
INTERNATIONAL JOURNAL OF ACADEMIC RESEARCH IN BUSINESS AND SOCIAL SCIENCES

Vol. 10, No. 6, June, 2020, E-ISSN: 2222-6990 @ 2020 HRMARS

Lee, C. K., \& Marshall, R. (1998). Measuring influence in family decision making process using an observational method. Qualitative market research: An international journal, 1(Number 2), pp. 88-98.

Lee, C. K., \& Collins, B. A. (2000). Family decision making and coalition patterns. European Journal of Marketing, 34(No. 9/10), pp. 1181-1198.

Mangleburg, T. F. (1990). Children's influence in purchase decisions: a review and critique. Advances in consumer research, 17, pp. 813-825.

Mangleburg, T. F., Grewal, D., \& Bristol, T. (1999). Family Type, Family Authority Relations, and Adolescents' Purchase Influence. Advances in Consumer Research, 26, pp.379-384

Marquis, M. (2004). Strategies for influencing parental decisions on food purchasing. Journal of Consumer Marketing, 21(Number 2), pp. 134-143.

Martinez, E., \& Polo, Y. (1999). Determining factors in family purchasing behavior: an empirical investigation. Journal of Consumer Marketing, 16(5), pp. 461-481.

May, H., \& Hearn, G. (2005). The mobile phone as media. International Journal of Cultural Studies, 8(2), pp. 195-211.

McDaniel, C., Charles W. Lamb, J., \& Joseph F.Hair, J. (2007). Marketing Essentials (Fifth ed.): Thomson South-Western.

McLaughlin, R. (2000). Targeting teens. Target Marketing, 23(1), pp. 84-87.

McNeal, J. U. (1992). The Littlest Shoppers. American Demographics, 14(2), pp. 48.

McNeal, J. U., \& Yeh, C. (1997). Development of consumer behavior patterns among chinese children. Journal of Consumer Marketing, 14(1), pp. 45-59.

Lührmann, M., Serra-Garcia, M., \& Winter, J. (2012). Teaching Teenagers in Finance: Does It Work? (Munich Discussion Paper). Ludwig-Maximilians-Universität München, Munchen.

Mittal, B., \& Soo-Lee, M. (1988). Separating brand-choice involvement from product involvement via consumer involvement profiles. Advances in Consumer Research, 15, pp.43-49.

Mittal, B. (1989). Measuring Purchase-Decision Involvement. Psychology and Marketing, 6, pp. 147162.

Opara, B. C., \& Uboegbulam, G. C. (2016). The Nigeria Perspective of Children's Impact on Purchase Decision Making For Durable Goods. International Journal of Arts \& Sciences, 07(05), 39-48.

Palan, K. M., \& Wilkes, R. E. (1997). Adolescent-parent interaction in family decision making. Journal of Consumer Research, 24, pp. 159-169.

Pallant, J. (2001). SPSS Survival Manual: A Step by step guide to data analysis using SPSS for Windows (Versions 10 and 11). Buckingham, Philadelphia: Open University Press.

Qualls, W. J. (1982). Changing sex roles: Its impact upon family decision making. Advances in Consumer Research, 9, pp. 267-270.

Roedder, D. L. (1981). Age differences in Children's response to television advertising: An information-processing aprroach. Journal of Consumer Research (1986-1998), 8(2), pp. 144154.

Røpke, I. (2003). Consumption dynamics and technological change exemplified by the mobile phone and related technologies. Ecological Economics, 45, pp. 171-188.

Sekaran, U. (2003). Research Methods for Business: A skill building approach (Fourth ed.): John Wiley and Sons, Inc., New York.

Sharma, A., \& Sonwaney, V. (2014). Theoretical Modeling of Influence of Children on Family urchase Decision Making. Procedia - Social and Behavioral Sciences, 133, 38-46. 
INTERNATIONAL JOURNAL OF ACADEMIC RESEARCH IN BUSINESS AND SOCIAL SCIENCES

Vol. 10, No. 6, June, 2020, E-ISSN: 2222-6990 @ 2020 HRMARS

Shoham, A., \& Dalakas, V. (2003). Family Consumer Decision Making in Israel: The role of teens and parents. Journal of Consumer Marketing, 20(3), pp. 238-251.

Shoham, A., \& Dalakas, V. (2005). He said, she said...they said: parents' and children's assessment of children's influence on family consumption decision. Journal of Consumer Marketing, 22(3), pp. 152-160.

Sidin, S. M., Zawawi, D., Wong, F. Y., Busu, R., \& Hamzah, Z. L. (2004). The effects of sex role orientation on family purchase decision making in Malaysia. Journal of Consumer Marketing, 21(6), pp. 381-390.

Spero, I., \& Stone, M. (2004). Agents of change: how young consumers are changing the world of marketing. Qualitative Market Research: An International Journal, 7(2), pp. 153-159.

Spiers, M. (2017). Families with adolescents: vacation decision making (Doctoral of Philosophy). Victoria University, Victoria.

Spiro, R. L. (1983). Persuasion in Family Decision Making. Journal of Consumer Research (pre-1986), 9(4), pp. 393-403.

Stone, M., Stanton, H., Kirkham, J., \& Pyne, W. (2001). The digerati: Generation Y finds its voice. Why cannot brands do the same? Journal of Targeting, Measurement and Analysis for Marketing, 10(2), pp. 158-167.

Su, C.-J., Liao, H.-H., Lorgnier, N., Yen, W.-S., Bouchet, P., Hirooka, Y., . . . Lan, Y.-F. (2019). easuring Adolescent Influence Tactics With Parents in Family Vacation Decisions: A Comparable Scale Across 19 Societies. SAGE Open, 9(1).

Talpade, S., \& Trilokekar-Talpade, M. (1995). Development of a multi-item scale to measure teenager influence on family purchase decisions: An exploratory study Journal of Marketing - Theory and Practice.

Vishwakarma, S., \& Chatterjee, R. (2018). Involving Cybernauts in Vacation Decisions. Gurukul Business Review, 14(Spring 2018), 37-41.

Wang, S., Holloway, B. B., Beatty, S. E., \& Hill, W. W. (2007). Adolescent influence in family purchase decisions: An update and cross-national extension. Journal of Business Research, 60, pp. 1117-1124.

Ward, S. (1974). Consumer Socialization. Journal of Consumer Research (1986-1998), 1(2).

Ward, S., \& Wackman, D. B. (1972). Children's purchase influence attempts and parental yielding. Journal of Marketing Research (pre-1986), 9, 316-319.

Wilska, T.-A. (2003). Mobile Phone Use as Part of Young People's Consumption Styles. Journal of Consumer Policy, 26, pp. 1441-463.

Wimalasiri, J. S. (2004). A cross-national study on children's purchasing behavior and parental response. Journal of Consumer Marketing, 21(Number 4), pp. 274-284.

Yapp, E., \& Khalid, H. A. (2006). SMS still king [Electronic Version]. The Star Online (Tech Central). Retrieved: 8th March, 2006 from http://startechcentral. com/tech/story.asp?file=/2006/1/31/technology/13265724\&sec=technology.

Ying, G. (2003). Consumption Patterns of Chinese Children. Journal of Family and Economic Issues, 24(4), pp. 373-379. 